\title{
Article
}

\section{Consumers' Awareness and Trust Toward Food Safety News on Social Media in Malaysia}

Soon, Jan Mei

Available at http://clok.uclan.ac.uk/31259/

Soon, Jan Mei ORCID: 0000-0003-0488-1434 (2020) Consumers' Awareness and Trust Toward Food Safety News on Social Media in Malaysia. Journal of Food Protection, 83 (3). pp. 452-459. ISSN 0362-028X

It is advisable to refer to the publisher's version if you intend to cite from the work. http://dx.doi.org/10.4315/0362-028X.JFP-19-415

For more information about UCLan's research in this area go to http://www.uclan.ac.uk/researchgroups/ and search for <name of research Group>.

For information about Research generally at UCLan please go to http://www.uclan.ac.uk/research/

All outputs in CLoK are protected by Intellectual Property Rights law, including Copyright law. Copyright, IPR and Moral Rights for the works on this site are retained by the individual authors and/or other copyright owners. Terms and conditions for use of this material are defined in the policies page. 


\title{
Research Note \\ Running title: Food safety news on social media
}

\section{Consumers' awareness and trust towards food safety news on social media in Malaysia}

\begin{abstract}
Social media offers numerous advantages for personal users and organisations to communicate, socialise and market one's products. When used correctly, social media is an effective tool to communicate and to share food safety news and good practices. However, there have been reports of fake food safety news shared via social media fuelling panic and resulting in loss of revenue. Thus, this study aims to investigate the consumers' awareness, trust and usage of social media in communicating food safety news in Malaysia. An online questionnaire divided into 5 sections: (i) demographics; (ii) reaction to food safety news; (iii) consumers' awareness; (iv) social media truth and level of trust; and (v) social media uses and content creation was created and shared online. A total of 341 questionnaires were returned of which 339 surveys were valid. This study revealed that less than one third of the study group (27.1\%) knew which of the food safety news were fake. $67.8 \%$ of the respondents were less likely to purchase the affected foods if the foods were featured in social media as problematic although no differences were made between true and fake news and how this would influence respondents' willingness to purchase affected foods. $62 \%$ of the respondents agreed or strongly agreed about the usage of social media and its ability to prevent food poisoning cases whilst more than $50 \%$ of the respondents were in total agreement that social media allow consumers to act more responsibly by sharing food safety news. Respondents tend to trust information shared by scientists (67.5\%) and family members and friends (33\%). Respondents would most often share the news after verifying its authenticity (46\%). If respondents experienced a personal food safety issue (e.g. discovered a fly in their meal), they seldom or never take photos to post online $(56.1 \%)$. It is possible that the respondents preferred to inform the food handlers and/or shop owners about the affected products rather than to post the photos online. It is suggested that targeted food safety
\end{abstract}


information and media literacy are provided to improve consumers' awareness and positively influence self-verification of the food safety information prior to sharing. This study provides crucial insights for a range of stakeholders, particularly public authorities, food bloggers and public to use social media effectively to build consumers' awareness and trust in food safety information.

Keywords: fake news; food safety; social media; trust

\section{HIGHLIGHTS}

- Respondents were aware of recent food safety news shown in social media

- Less than one third of the study group knew which of the food safety news was fake

- Targeted food safety information should be provided to improve consumers' awareness

Social media refer to an internet-based application such as social networks, blogs, content sharing sites and wikis (19). Examples of social media include Facebook, Google+, Instagram, Pinterest, Wechat, Whatsapp and YouTube. Facebook dominates social media usage where $68 \%$ of American adults (50), $77 \%$ of the European population (54) and $75 \%$ Asians (55) use Facebook. In Malaysia, $82.75 \%$ of the population engages with Facebook followed by Twitter (5.14\%), YouTube (4.68\%), Pinterest (3.83\%), Instagram (2.05\%) and Tumblr (1.09\%) (56). Social media offer numerous advantages for individuals to communicate, socialise, play games, create and exchange content and post pictures. Along with the positive social aspects, there is also a dark side to social media, including (but not limited to) spreading of fake news and hoaxes (17).

Internet fake news is defined as 'fictitious articles deliberately fabricated to deceive readers' (1). Social media rely on users to create and share content which bypass the process of fact checking, editorial judgement and gatekeeping (25). Fake news is often created for financial or ideological purposes. For example, fake stories that go viral (the more sensational, the better), provide content producers with more clicks which translate into more revenues. Fake news is also produced to promote ideas or people or to discredit others $(3,57)$. Fake and misleading news may pose serious implications for public health. A prominent example was the alleged link between measles, mumps and rubella (MMR) vaccine and autism study in the UK (60) which led to an increased fear of vaccines 
across developed countries (45). Another study by Waszak et al. (61) revealed that $40 \%$ of the most frequently shared links in social media contained misinformation and were shared more than 400,000 times between 2012-2017. Recently, there's been a spike in online fake news in Asia particularly China. Most online fake news in China were related to food safety (63) including the sale of plastic seaweed (53), seedless grapes produced with contraceptive drugs (15) and the cardboard bun hoax (23). For example, in China, a freelance reporter hired several workers to make cardboard buns whilst he filmed the production. The footage was later aired via television and online media and received worldwide media attention and shock among consumers. The journalist was later arrested for faking an investigative report $(42,65)$. Fake news were also shared in Malaysia such as fake eggs in 2014 (14), plastic in crackers $(6,12)$ and Salmonella outbreak linked to water supply (26). The majority of Malaysians received fake news via Whatsapp followed by Facebook (37).

When used correctly, social media had proven to be an effective food safety communication tool due to its speed, accessibility, interactive and information gathering capacities $(43,47,64)$. For example, social media could be used as a complementary information channel in addition to traditional and online media to find food safety information (27). Mayer and Harrison (34) evaluated a 'Safe Eats' facebook intervention and reported an increase in food safety knowledge, attitudes and practices among the respondents. In China, micro-blogs such as 'We media' (a Chinese version of Twitter) had proven useful in disseminating food safety awareness among public. Food safety scandals exposed by We media were found to affect consumers' purchasing behaviour and a reduction in sales volume of the affected products (44). This demonstrates that if social media is used correctly, it is an effective tool to improve food safety among public. Although the use of social media in communicating food safety information had been carried out extensively (43), the factors that influence social media practices and spread of fake food safety news remained understudied.

Food safety awareness and knowledge among consumers and food handlers have always been of interest to researchers. Knowledge forms part of the 'Knowledge, Attitudes and Practices' (KAP) model used to evaluate food safety and hygiene among food handlers ( 8 ) and consumers (41). It is based on the premise that users who had been educated with food safety knowledge, can improve their food safety practices (69). In the context of this study, the provision of food safety news or information could provide viewers with an increased awareness of the situation. 
Trust has commonly been identified as a crucial factor in consumers' food decision (24). The general objective of trust aims at a positive and confident feeling in a provider's reliability. In the social media and food safety information context, trust refers to confidence in the provider of food safety news or information (24). Lobb et al. (31) revealed that trust in food safety information provided by media, alternative sources such as consumer organisations and independent authorities such as scientists reduces the likelihood to purchase affected food products. Thus, this study aims to investigate the awareness, trust and usage of social media in communicating food safety news among Malaysian consumers.

\section{MATERIALS AND METHODS}

The questionnaire was constructed and divided into 5 sections: (i) demographics (4 questions); (ii) reaction to food safety news (6 questions); (iii) consumers' awareness (8 questions); (iv) social media truth and trust (8 questions); and ( $v$ ) social media uses and content creation (8 questions). The questions were developed based on Chai et al. (13), Frewer et al. (22) and Lobb et al. (31). In Section II (reaction to food safety news), respondents were also asked to select which of the food safety news was fake. Five options were provided i.e. (i) China sardines found to contain worms; (ii) fake baby formula; (iii) fake eggs sold in market in 2014; (iv) Australia melons contaminated with deadly bacteria; and (v) Uncertain. Options i, ii and iv were actual news whilst the fake eggs sold in market in 2014 was false news. In the consumers' awareness, usage and trust sections, respondents were asked to rate on a 5-point Likert scale of strongly disagree (1) to strongly agree (5). In the social media practice section, respondents were asked to rate on a 5-point frequency scale of never (1) to always (5). Respondents were invited to complete all sections. The questionnaire was provided in both English and Malay languages. A pilot study was conducted among 10 respondents who were not included in the actual study to evaluate the language, clarity and suitability of wording. The questionnaire was uploaded onto an online survey system (previously known as Bristol Online 
System) and recruits respondents over the age of 18 in Malaysia from social media sites.

Respondents using social media were encouraged to post the link in their own social media page to generate more responses via the snowballing technique. Snowball sampling is particularly useful in identifying potential targeted subjects (e.g. respondents who use social media) where subjects are hard to locate (2). A total of 341 questionnaires were returned of which 339 surveys were valid.

\section{RESULTS AND DISCUSSION}

The respondents were highly represented by the Generation Y or Millenial group (age: $26-35$ years) $(67.8 \%)$, females $(61.9 \%)$ and those with tertiary education (95.3\%). Facebook $(97.1 \%)$, Whatsapp (91.7\%), YouTube (79.1\%) and Instagram (74.9\%) were frequently used by the study group (Table 1). More than $70 \%$ of the respondents have heard of the fake baby milk formula incident (Table 2). Of the four food safety news, 27.1\% knew that the fake egg incident in 2014 was false news as the national health authority had conducted the investigation and verified that no fake eggs were sold in the local market (36). More than $35 \%$ of the respondents believed that the Australian melons contaminated with Listeria monocytogenes were fake although the outbreak was real and occurred between January - April 2018 and resulted in seven deaths and one miscarriage (40). Most respondents were less likely to purchase the affected foods (67.8\%) when such news were shared. However, no differences were made between true and fake news and how this would influence respondents' willingness to purchase affected foods. Respondents were given a hypothetical scenario in Table 2 to determine their reaction to the post. More respondents opted to verify the claim with the right authorities (45.1\%) followed by asking User B to verify the authenticity of the claim (24.8\%).

Overall, $62 \%$ of the respondents agreed or strongly agreed about the usage of social media and its ability to prevent food poisoning cases (Table 3). More than $50 \%$ of the respondents were in total agreement that social media allow consumers to act more responsibly by sharing food safety news. Similarly, there were strong agreement among the respondents that fake news shared on social media can generate panic among consumers (49.9\%). This study also revealed some interesting findings on why the respondents took photos of foods. Those who took photos intended to introduce and/or share the photos with their online peers (64\%) or were treating the online photobook like 
their food diary (16.8\%) (Table 3). Respondents trusted the food safety news if the content were shared by scientists $(67.5 \%)$, followed by their family members and friends $(33 \%)$ and food bloggers (30\%) (Figure 1). $42.4 \%$ of the respondents do not trust the food safety news if shared by strangers. Similarly, the level of trust declines slightly if the news were shared by politicians ( $25.4 \%)$ or celebrities (31.8\%).

There was high level of agreement among respondents (73.7\%) that they will verify the authenticity of food safety related news using other sources. The respondents seldom or never created $(77 \%)$, provided their views $(82.6 \%)$ nor shared food safety news promptly with their online peers (53.4\%). They would most often share the news after verifying its authenticity (46\%) while $43.9 \%$ frequently read the news without sharing them. If respondents experienced a food safety issue personally such as discovering a fly in their meal or came across expired food products in a shop, they seldom or never take photos to post online (56.1\%) (Table 3).

The millenials are those born between 1981 - 2000 and are called digital natives as they actively use, share and create content on social media platforms (7). Curtin et al. (18) reported that educated people were also more likely to participate in surveys. This explains the higher number of respondents from the millennial and educated group. Although other generations now recognise and appreciate social media platforms, millennials are the first generation to have spent most of their lives immersed in digital technology (62). Females dominated the response group in this study although males (38.1\%) outnumbered women in the distribution of Internet users in Malaysia (33). This is attributable to the subject matter where females are more responsive to food safety information as females dominate food purchasing and preparation role (28). Previous studies related to food safety knowledge in Malaysia also recorded higher female responses $(41,51)$. The usage of social media application is reflected in the national survey carried out in 2017 where the top three social networking accounts owned by Internet users in Malaysia were Facebook, Instagram and YouTube (33).

The high number of respondents who have heard of the fake baby formula is potentially driven by the melamine milk scandal since 2008 . The fake baby formula scare re-emerged recently where counterfeit products were seized and withdrawn from retailers (10). Although the fake egg incident in 2014 was false, fake eggs had appeared in China since the mid-1990s (20). Multiple YouTube videos 
$(66,68)$, online news and social media platform such as personal blogs and forum (46) showed viewers how to identify fake eggs.

Fake news can be disruptive to the society. For example, due to allegations of seaweed made from plastic, seaweed producers in China suffered from a huge loss of revenue (53). Nevertheless, social media can be a useful tool to report food poisoning cases or to report unhygienic food businesses. This was evident in a recent incident in Malaysia where food handlers were filmed washing dishes in a puddle of dirty water by the roadside (38). The film was shared on social media over YouTube, blogs, Twitter, Whatsapp and online news. It went viral and garnered more than 300,000 views and 750 comments. The comments were not analysed in this study, but similar thoughts i.e. 'boycott the restaurant', 'ban', 'hygiene', 'health authorities' and 'inspection' were commonly expressed by netizens (67). This incident although unfortunate demonstrates clearly that consumers' awareness of food safety news via social media can influence users' practices. Ultimately, the restaurant was closed down by local health authorities for unhygienic practices (59).

Although the practice of using social media as a reporting tool is still not studied in Malaysia, studies had been conducted elsewhere. For example, Twitter is used to capture potential number of patrons who fell ill after eating at certain venues (48) and social media and food business review sites could be used to mine data on foodborne illness and outbreaks (39). There is still untapped potential in using social media effectively as a driving and reporting tool to ensure food safety (52). A food safety benefit could be derived from online foodism. Food photos can help users to recall foods eaten, date and venue - and is exceptionally useful in assisting surveillance and epidemiological investigation if an outbreak occurs. This is similar to using loyalty / membership card to analyse grocery purchases to investigate outbreaks (5).

The findings on trust in food safety news concurred with previous studies that reported scientists were one of the most trusted sources for scientific information $(9,30)$. Hence, it is crucial that scientists and researchers build and maintain public trust in food and health as the credibility of the food system is extremely vulnerable during food scares and/or crisis (16). Interestingly, food bloggers evoked similar level of trust as family members and friends. Bloggers usually discuss a topic of interest primarily focused on food topics such as recipes, restaurant reviews, travel, food ethics, food safety and food aesthetics which are commented on by other readers (32). Readers with interest 
in similar topics will interact and 'follow' the blogger hence creating a close online relationship in the blogging community.

Malaysians are known for their strong family connections and trust among family circles and peers (35). Lange et al. (29) reported similar findings where young consumers trusted their family members as credible sources of food safety knowledge. A prevalent practice among local Malaysian culture is distrust of strangers and people not belonging to their circle (35). This explains the level of distrust of food safety news shared by strangers. Frewer et al. (22) revealed that politicians generate a low level of trust as they could be perceived to have vested interest in the topic. Another crucial factor is that some food safety news were fabricated. Viewers can view the story 'in real-time' but it is possible that with multiple cases of false information shared online, this has increased the level of distrust among general public. The respondents in this study reported that they will verify the authenticity of food safety related news using other sources and is similar to Freberg (21) where users tend to comply with organisational food recall messages compared to user-generated content.

Respondents seldom or never take photos of food safety issues (e.g. a fly in their meal) that they experienced. It is possible that the respondents preferred to inform the food handlers and/or shop owners about the affected products rather than to post the photos online. Malaysians tend avoid public humiliation of others to prevent one from losing 'face' (to lose 'face' is a colloquial term meaning to be publicly humiliated). However, there are increasing reports of unhygienic food premises shared online that made its way into mainstream news showing that major food safety issues are better shared to ensure relevant actions are taken $(38,58)$.

Social media is a promising tool in strengthening public awareness and to build trust when used correctly. Fake news has a long history and is probably here to stay. Safeguards are required to deter, detect and control the spread of falsified information. Measures are adopted by Facebook to stop fake news by sending potentially false stories to independent fact checkers (11). Andorfer (4) suggested regulating fake news but is aware that such legal proposal should be treated with caution. Malaysia proposed an 'Anti-Fake News Bill' where those convicted of disseminating false information would be jailed up to 10 years or fined or both (12). The Bill was repealed as it was described as an attempt to silent dissent (this was before the historic 2018 Malaysian general election) and curtailed freedom of speech (49). Artificial intelligence and machine learning algorithms are being developed to 
detect fake news by analysing language, number of words, punctuation marks, usage of hyperbole and slang phrases $(1,4)$. Self-verification of food safety information and reporting potential (fake) food safety news to public authorities are simple steps that could be carried out by general public.

Facebook, Whatsapp and YouTube represent the top social media platforms used by the respondents. Most were aware of recent food safety news shown in social media but less than one third of the group knew which of the news was fake. There was a moderate level of awareness among the respondents regarding the possibility of social media being used as an effective food safety dissemination tool. Scientists were accorded the highest level of trust followed by family members and food bloggers. Respondents were found to prefer sharing or reposting of information rather than creating food-related content. It is suggested that targeted food safety information and media literacy are provided to improve consumers' awareness and positively influence self-verification of the information prior to sharing. Clarity and transparency in communication by public authorities can build trust in food safety information. Looking beyond the scope of the current study, future research could investigate the extent and spread of fake and actual food safety news and how this impacts consumers' trust and purchasing decisions. Food bloggers were perceived as credible source of information and the social capital trust created online warrants further investigation.

\section{REFERENCES}

1. Aldwairi, M., and A. Alwahedi. 2018. Detecting fake news in social media networks. Procedia Comp. Sci. 141: 215-222.

2. Ali, A., X. Guo, M. Sherwani, and A. Ali. (2017). Factors affecting Halal meat purchase intention: Evidence from international Muslim students in China. Brit. Food J. 119(3): 527-541.

3. Allcott, H., and M. Gentzkow. 2017. Social media and fake news in the 2016 election. J. Econ. Perspect. 31(2): 211-236.

4. Andorfer, A. 2017. Spreading like wildfire: Solutions for abating the fake news problem on social media via technology controls and government regulation. Hastings Law J. 69: 1409-1432. 
5. Barret, A. S., M. Charron, P. Mariani-Kurkdjian, M. Gouali, E. Loukiadis, B. Poignet-Lerouz, et al. 2013. Shopper cards data and storage practices for the investigation of an outbreak of Shigatoxin producing Escherichia coli 0157 infections. Med. Maladies Infect. 43(9): 368-373.

6. Bedi, R. S. 2016. Health Ministry says no evidence of plastic in Hup Seng crackers. The Star Online, 8 August. Available at: https://www.thestar.com.my/news/nation/2016/08/08/healthministry-says-no-evidence-of-plastic-in-hup-seng-crackers/ Accessed 4 July 2019.

7. Bolton, R. N., A. Parasuraman, A. Hoefnagels, N. Migchels, S. Kabadayi, T. Gruber, Y. K. Loureiro, and D. Solnet. 2013. Understanding generation $\mathrm{Y}$ and their use of social media: a review and research agenda. J. Serv. Manage. 24(3): 245-267.

8. Bou-Mitri, C., D. Mahmoud, N. El Gerges, and M. A. Jaoude. 2018. Food safety knowledge, attitudes and practices of food handlers in Lebanese hospitals: A cross-sectional study. Food Control 94: 78-84.

9. Brewer, P. R., and B. L. Ley. 2012. Whose science do you believe? Explaining trust in sources of scientific information about the environment. Sci. Commun. 35(1): 115-137.

10. British Broadcasting Corporation (BBC). 2017a. Fake baby formula scare hits Malaysia. BBC News, 14 December. Available at: https://www.bbc.co.uk/news/business-42348254 Accessed 13 May 2019.

11. British Broadcasting Corporation (BBC). 2017b. Facebook ditches fake news warning flag. BBC News, 21 December. Available at: https://www.bbc.co.uk/news/technology-42438750 Accessed 20 July 2019.

12. British Broadcasting Corporation (BBC). 2018. Malaysia seeks 10-year jail terms for 'fake news'. BBC News, 26 March. Available at: https://www.bbc.co.uk/news/world-asia-43538109 Accessed 20 July 2019.

13. Chai, S., S. Das, and H. R. Rao. 2011. Factors affecting bloggers' knowledge sharing: An investigation across gender. J. Manage. Inform. Syst. 28(3): 309-342. 
14. Cheah, C. 2014. No fake eggs on sale here. The Star Online, 24 September. Available at: https://www.thestar.com.my/news/nation/2014/09/24/no-fake-eggs-on-sale-here-process-ofgrading-will-detect-any-anomaly-says-health-dg/ Accessed 4 July 2019.

15. China.org.cn. 2016. Seedless grape rumours hurt farmers. Available at: http://www.china.org.cn/china/2016-09/06/content 39242049.htm Accessed 30 June 2019.

16. Coveney, J., L. Mamerow, A. Taylor, J. Henderson, S. Myer, and P. Ward. 2012. Comparative examination of trust during times of a food scandal in Europe and Australia. Food Pub. Health 2(6): 202-212.

17. Craker, N., and E. March. 2016. The dark side of Facebook ${ }^{\circledR}$ : The Dark Tetrad, negative social potency, and trolling behaviours. Pers. Indiv. Differ. 102: 79-84.

18. Curtin, R., S. Presser, and E. Singer. 2000. The effects of response rate changes on the index of consumer sentiment. Public Opin. Quart. 64(4): 413-428.

19. Eurostat. 2018. Social media - statistics on the use by enterprises. Available at: https://ec.europa.eu/eurostat/statistics-explained/index.php/Social media statistics on the use by enterprises\#Further Eurostat information Accessed 30 June 2019.

20. Evershed, R., and N. Temple. 2016. Introduction: Not eggsactly what you thought. Sorting the beef from the bull: The science of food fraud forensics. Bloomsbury Sigma, London.

21. Freberg, K. 2012. Intention to comply with crisis messages communicated via social media. Public Relat. Rev. 38(3): 416-421.

22. Frewer, L. J., C. Howard, D. Hedderley, and R. Shepherd. 1996. What determines trust in information about food-related risks? Underlying psychological constructs. Risk Anal. 16(4): 473486.

23. Grace, F. 2007. China busts cardboard bun shop. CBS News, 12 July 2007. Available at: https://www.cbsnews.com/news/china-busts-cardboard-bun-shop/ Accessed 30 June 2019.

24. Hobbs, J. E., and E. Goddard. 2015. Consumers and trust. Food Policy 52: 71-74. 
25. Jang, S. M., and J. K. Kim. 2018. Third person effects of fake news: Fake news regulation and media literacy interventions. Comput. Hum. Behav. 80: 295-302.

26. Kannan, H. K. 2018. Health Ministry rubbishes Salmonella outbreak in Klang Valley. News Strait Times, 3 March. Available at: https://www.nst.com.my/news/nation/2018/03/340941/healthministry-rubbishes-salmonella-outbreak-klang-valley Accessed 4 August 2019.

27. Kuttschreuter, M., P. Rutsaert, F. Hilverda, A. Regan, J. Barnett, and W. Verbeke. 2014. Seeking information about food-related risks: The contribution of social media. Food Qual. Prefer. 37: 1018.

28. Lake, A. M., R. M. Hyland, J. C. Mathers, A. J. Rugg-Gunn, C. E. Wood, and A. J. Adamson. 2006. Food shopping and preparation among the 30-somethings: whose job is it? (The ASH30 study). Brit. Food J. 108(6): 475-486.

29. Lange, M., F. L. Goranzon, and I. Marklinder. 2018. 'Adolescents' sources for food safety knowledge and trust. Brit. Food J. 120(3): 549-562.

30. Liu, R., Z. Pieniak, and W. Verbeke. 2014. Food-related hazards in China: Consumers' perceptions of risk and trust in information sources. Food Control 46: 291-298.

31. Lobb, A. E., M. Mazzocchi, and W. B. Traill. 2007. Modelling risk perception and trust in food safety information within the theory of planned behaviour. Food Qual. Prefer. 18(2): 384-395.

32. Lofgren, J. 2013. Food blogging and food-related media convergence. M/C Journal, 16(3). Available at: http://www.journal.media-culture.org.au/index.php/mcjournal/article/view/638 Accessed 15 May 2019.

33. Malaysian Communications and Multimedia Commission (MCMC). 2017. Internet users survey 2017. Available at: https://www.mcmc.gov.my/skmmgovmy/media/General/pdf/MCMCInternet-Users-Survey-2017.pdf Accessed 13 May 2019.

34. Mayer, A. B., and J. A. Harrison. 2012. Safe Eats: An evaluation of the use of social media for food safety education. J. Food Prot. 75(8): 1453-1463. 
35. Mosbah, A., and K. A. Wahab. 2018. Chinese family business in Malaysia: Development, culture and the family business philosophy. Int. J. Acad. Res. Bus. Soc. Sci. 8(5): 1013-1021.

36. New Strait Times (NST). 2015. No fake eggs in local market. New Straits Times, 24 August 2015. Available at: https://www.nst.com.my/news/2015/09/no-fake-eggs-local-market Accessed 13 May 2019.

37. New Strait Times (NST). 2018a. Whatsapp, Facebook main sources of fake news for Malaysians. New Straits Times, 26 March. Available at:

https://www.nst.com.my/news/nation/2018/03/349523/whatsapp-facebook-main-sourcesfake-news-malaysians Accessed 4 May 2019.

38. New Strait Times (NST). 2018b. MOH issues three offences notices against Raj's Banana Leaf Restaurant. New Strait Times, 31 May. Available at:

https://www.nst.com.my/news/nation/2018/05/374992/moh-issues-three-offence-noticesagainst-rajs-banana-leaf-restaurant Accessed 15 May 2019.

39. Nsoesie, E. O. 2016. Use of digital social media in food safety monitoring and surveillance. Crowdsourcing and novel digital data: 21st century tools for food safety monitoring, surveillance, and management. IAFP Annual Meeting, Jul 31 - Aug 3, St. Louis, Missouri, USA.

40. NSW Department of Primary Industries (NSW DPI). 2018. Listeria outbreak investigation Summary report for the melon industry. Available at:

http://www.foodauthority.nsw.gov.au/ Documents/foodsafetyandyou/listeria outbreak invest igation.pdf Accessed 13 May 2019.

41. Odeyemi, O. A., N., Abdullah Sani, A. O. Obadina, C. K. S. Saba, F. A. Bamidele, M. Abughoush, A. Asghar, F. F. D. Dongmo, D. Macer, and A. Aberoumand. 2019. Food safety knowledge, attitudes and practices among consumers in developing countries: An international survey. Food Res. Int. doi: 10.1016/j.foodres.2018.10.030

42. Olesen, A. 2007. Beijing's cardboard-stuffed buns a hoax. The Washington Post, 19 July. Available at: http://www.washingtonpost.com/wp- 


\section{dyn/content/article/2007/07/19/AR2007071901138.html??noredirect=on Accessed 18}

December 2018.

43. Overbey, K. N., L.-A. Jaykus, L.-A., and B. J. Chapman. 2017. A systematic review of the use of social media for food safety risk communication. J. Food Prot. 80(9): 1537-1549.

44. Peng, Y., J. Li, H. Xia, S. Qi, and J. Li. 2015. The effects of food safety issues released by we media on consumers' awareness and purchasing behavior: A case study in China. Food Policy 51: 44-52.

45. Peters, A., Tartari, E., Lotfinejad, N., Parneix, P., \& Pittet, D. (2018). Fighting the good fight: the fallout of fake news in infection prevention and why context matters. J. Hosp. Infect. 100(4), 365-370.

46. Quora. 2016. How do I distinguish between artificial egg from natural egg? Available at: https://www.quora.com/How-do-I-distinguish-between-artificial-egg-from-natural-egg Accessed 13 May 2019.

47. Rutsaert, P., Z. Pieniak, A. Regan, A. McConnon, M. Kuttschreuter, M. Lores, M. et al. 2014. Social media as a useful tool in food risk and benefit communication? A strategic orientation approach. Food Policy 46: 84-93.

48. Sadilek, A., H. Kautz, L. DiPrete, B. Labus, E. Portman, J. Teitel, and V. Silenzio. 2016. Deploying nEmesis: Preventing foodborne illness by data mining social media. AAAI 3982-3990.

49. Sivanandam, H., M. Carvalho, R. Rahim, and L. K. Shagar. 2018. Parliament passes bill to repeal Anti-Fake News law. The Star Online, 16 August. Available at:

https://www.thestar.com.my/news/nation/2018/08/16/parliament-passes-bill-to-repeal-antifake-news-law/ Accessed 20 May 2019.

50. Smith, A., and M. Anderson. 2018. Social media use in 2018. Pew Research Center: Internet \& Technology. Available at: http://www.pewinternet.org/2018/03/01/social-media-use-in-2018/ Accessed 3 May 2019.

51. Soon, J. M. 2018. Structural modelling of food allergen knowledge, attitude and practices among consumers in Malaysia. Food Res. Inter. 111: 674-681. 
52. Soon, J. M., and S. Saguy. 2017. Crowdsourcing: A new conceptual view for food safety and quality. Trends Food Sci. Tech. 66: 63-72.

53. South China Morning Post (SCMP). 2017. 'Plastic' seaweed? Chinese producers lose millions after rumours spread through viral video. SCMP, 28 February 2017. Available at:

https://www.scmp.com/news/china/society/article/2074686/chinese-seaweed-producers-losemillions-over-plastic-product Accessed 30 June 2019.

54. StatCounter. 2018a. Social media stats Europe. Available at: http://gs.statcounter.com/socialmedia-stats/all/europe Accessed 3 May 2019.

55. StatCounter. 2018b. Social media stats Asia. Available at: http://gs.statcounter.com/socialmedia-stats/all/asia Accessed 3 May 2019.

56. StatCounter. 2018c. Social media stats Asia. Available at: http://gs.statcounter.com/socialmedia-stats/all/malaysia Accessed 3 May 2019.

57. Tandoc, E. C., Z. W. Lim, and R. Ling. 2017. Defining "fake news". J. Digit. Journalism 6(2): 137153.

58. The Star Online. 2018a. Raj's Banana Leaf outlet faces closure following dirty dishes video. The Star Online, 29 May. Available at: https://www.thestar.com.my/news/nation/2018/05/29/rajbanana-leaf-outlet-faces-closure-following-dirty-dishes-video/ Accessed 15 May 2019.

59. The Star Online. 2018b. DBKL officially shuts down Bangsar banana leaf restaurant. The Star Online, 30 May. Available at: https://www.thestar.com.my/news/nation/2018/05/30/dbklhealth-inspectors-come-a-calling-at-bangsar-banana-leaf-restaurant/ Accessed 18 May 2019.

60. Wakefield, A. J., S. H. Murch, A. Anthony, J. Linnell, D. M. Casson, M. Malik et al. 1998.

RETRACTED: Illeal-lymphoid-nodular hyperplasia, non-specific colitis and pervasive developmental disorder in children. Lancet 351(9103): 637-641.

61. Waszak, P., W. Kasprzycka-Waszak, and A. Kubanek. 2018. The spread of medical fake news in social media - The pilot quantitative study. Health Policy and Techn. 7(2): 115-118. 
62. Wesner, M. S., and T. Miller. 2008. Boomers and millennials have much in common. Organ. Dev. J. 26(3): 89.

63. Whitehead, R. J. 2017. Most Chinese 'fake news' stories involve food safety. Food NavigatorAsia. Available at: https://www.foodnavigator-asia.com/Article/2017/04/24/Most-Chinese-fakenews-stories-involve-food-safety\# Accessed 30 June 2019.

64. Wu, C.-W. 2015. Facebook users' intentions in risk communication and food safety issues. J. Bus. Res. 68(11): 2242-2247.

65. YouTube. 2007. Buns made of chopped cardboard. Available at: https://www.youtube.com/watch?v=svPWuEFitNI Accessed 18 May 2019.

66. YouTube. 2014. A consumer explains how to identify a fake egg. Available at: https://www.youtube.com/watch?v=nD5auTOFnpc Accessed 13 May 2019.

67. YouTube. 2018. Workers at Raj Banana Leaf restaurant in Bangsar caught washing dishes with dirty water. Available at: https://www.youtube.com/watch?v=C6Px8se15XQ Accessed 13 May 2019.

68. YouTube. 2019. How to check fake eggs. Available at: https://www.youtube.com/watch?v=Rdyg9WluxXY Accessed 13 May 2019.

69. Zanin, L. M., D. T. da Cunha, V. V. de Rosso, V. D. Capriles, and E. Stedefeldt. 2017. Knowledge, attitudes and practices of food handlers in food safety: An integrative review. Food Res. Int. 100(Part 1): 53-62. 
FIGURE 1. Trust in food safety news shared by different individuals via social media $(n=339)$ 
TABLE 1. Demographics of respondents $(n=339)$

\begin{tabular}{llc}
\hline Items & Categories & Frequency (\%) \\
\hline Gender & Male & $129(38.1)$ \\
& Female & $210(61.9)$ \\
Age & $18-25$ years & \\
& $26-35$ years & $73(21.5)$ \\
& $36-45$ years & $230(67.8)$ \\
Education & $46-55$ years & $17(5.0)$ \\
& $56-65$ years & $10(2.9)$ \\
Social media & Secondary & $9(2.7)$ \\
application used* & Tertiary & $16(4.7)$ \\
& & Facebook \\
& Whatsapp & $323(95.3)$ \\
& YouTube & $329(97)$ \\
& Instagram & \\
& Wechat & $311(92)$ \\
& Google + & $268(79)$ \\
& LinkedIn & $254(75)$ \\
& Twitter & $195(58)$ \\
& Skype & $108(32)$ \\
& Line & $90(27)$ \\
& Pinterest & $73(22)$ \\
& Others (Snapchat, Telegram) & $67(20)$ \\
& Reddit & $47(14)$ \\
& Tumblr & $36(11)$ \\
& & $21(6)$ \\
& & $10(3)$ \\
& & $8(2)$ \\
\hline
\end{tabular}


TABLE 2. Food safety news and respondents' reactions $(n=339)$

\begin{tabular}{|c|c|c|}
\hline Food safety news & Items & Frequency (\%) \\
\hline $\begin{array}{l}\text { The following are examples of } \\
\text { recent food safety news. Which one } \\
\text { did you come across in social } \\
\text { media? a }\end{array}$ & $\begin{array}{l}\text { China sardines found to contain } \\
\text { worms } \\
\text { Fake baby milk formula } \\
\text { Fake eggs sold in market in } 2014 \\
\text { Australia melons contaminated with } \\
\text { deadly bacteria }\end{array}$ & $\begin{array}{l}199(58.7) \\
262(77.3) \\
209(61.7) \\
107(31.6)\end{array}$ \\
\hline Which one of the news is fake? & $\begin{array}{l}\text { China sardines found to contain } \\
\text { worms } \\
\text { Fake baby formula } \\
\text { b Fake eggs sold in market in } 2014 \\
\text { Australia melons contaminated with } \\
\text { deadly bacteria } \\
\text { Uncertain }\end{array}$ & $\begin{array}{l}68(20.1) \\
49(14.5) \\
92(27.1) \\
125(36.9) \\
49(14.5)\end{array}$ \\
\hline $\begin{array}{l}\text { After hearing some of the food } \\
\text { safety news above, will you } \\
\text { purchase the affected food? }\end{array}$ & $\begin{array}{l}\text { Yes } \\
\text { No } \\
\text { Maybe }\end{array}$ & $\begin{array}{l}17(5.0) \\
230(67.8) \\
92(27.1)\end{array}$ \\
\hline \multicolumn{3}{|c|}{$\begin{array}{l}\text { The following is a hypothetical case scenario. You are a consumer who loves Brand A's beverage. If } \\
\text { user B claims that foreign materials were found in Brand A's beverages and the post went viral in } \\
\text { Facebook: }\end{array}$} \\
\hline What is your reaction to the post? & $\begin{array}{l}\text { Share it } \\
\text { Comment to User B to verify the } \\
\text { authenticity of the claim } \\
\text { Delete it } \\
\text { Comment to User B to remove the } \\
\text { post } \\
\text { Check the claim with the right } \\
\text { authorities }\end{array}$ & $\begin{array}{c}52(15.3) \\
84(24.8) \\
2(0.6) \\
0 \\
153(45.1)\end{array}$ \\
\hline
\end{tabular}




\begin{tabular}{llc}
\hline & $\begin{array}{l}\text { Others (e.g. stop buying the } \\
\text { product, ignore post, wait for } \\
\text { official news) }\end{array}$ & $48(14.2)$ \\
& & \\
$\begin{array}{l}\text { Will you continue to purchase } \\
\text { Brand A's drinks? }\end{array}$ & $\begin{array}{l}\text { Yes } \\
\text { No }\end{array}$ & $8(2.4)$ \\
& Maybe, I will verify the claim first & $55(16.2)$ \\
Will you think that it's just a prank & Yes & $276(81.4)$ \\
and will continue to support Brand & No & $23(6.8)$ \\
A? & Maybe, I will verify the claim first & $41(12.1)$ \\
& & $275(81.1)$ \\
\hline
\end{tabular}

Note: ${ }^{a}$ Respondents can select more than one option; ${ }^{b}$ Correct answer (Note that the news on fake eggs sold in market in 2014 was false)

TABLE 3. Consumers' awareness, trust and usage of food safety news and/or information on social media $(n=339)$

\begin{tabular}{|c|c|c|c|c|c|}
\hline \multirow[t]{2}{*}{ Awareness } & \multicolumn{5}{|c|}{ Frequency (\%) } \\
\hline & $\begin{array}{l}\text { Strongly } \\
\text { disagree }\end{array}$ & Disagree & $\begin{array}{l}\text { Neither } \\
\text { agree nor } \\
\text { disagree }\end{array}$ & Agree & $\begin{array}{c}\text { Strongly } \\
\text { agree }\end{array}$ \\
\hline $\begin{array}{l}\text { I get most food safety related } \\
\text { news from social media }\end{array}$ & 4.7 & 13.6 & 22.4 & 46.9 & 12.4 \\
\hline $\begin{array}{l}\text { My peers often share food } \\
\text { safety news with me }\end{array}$ & 5.0 & 12.1 & 26.3 & 49.3 & 7.4 \\
\hline $\begin{array}{l}\text { Social media can help prevent } \\
\text { food poisoning cases }\end{array}$ & 4.7 & 10.0 & 23.3 & 48.4 & 13.6 \\
\hline $\begin{array}{l}\text { Fake news can generate panic } \\
\text { among consumers }\end{array}$ & 5.9 & 3.2 & 6.5 & 34.5 & 49.9 \\
\hline $\begin{array}{l}\text { Social media allow general } \\
\text { consumers to act more } \\
\text { responsibly by sharing food } \\
\text { safety news }\end{array}$ & 7.7 & 9.7 & 28.3 & 38.6 & 15.6 \\
\hline $\begin{array}{l}\text { Social media can be used as a } \\
\text { reporting tool to report } \\
\text { unhygienic food businesses }\end{array}$ & 5.9 & 7.4 & 16.8 & 49.3 & 20.6 \\
\hline $\begin{array}{l}\text { Social media encourages food } \\
\text { stalls to be hygienic and serve } \\
\text { safe food }\end{array}$ & 4.7 & 7.4 & 19.2 & 44.5 & 24.2 \\
\hline $\begin{array}{l}\text { Taking photos of food can help } \\
\text { me to remember the food I've } \\
\text { eaten }\end{array}$ & 6.8 & 14.7 & 25.7 & 37.5 & 15.3 \\
\hline $\begin{array}{l}\text { Reasons for taking photos of } \\
\text { food }\end{array}$ & $\begin{array}{l}\text { Frequency } \\
(\%)\end{array}$ & & & & \\
\hline It's my hobby & $41(12.1)$ & & & & \\
\hline $\begin{array}{l}\text { I like to share photos of food } \\
\text { online }\end{array}$ & $100(29.5)$ & & & & \\
\hline $\begin{array}{l}\text { I like people to comment on the } \\
\text { photos }\end{array}$ & $10(2.9)$ & & & & \\
\hline
\end{tabular}




\begin{tabular}{|c|c|c|c|c|c|}
\hline $\begin{array}{l}\text { I want to introduce the food to } \\
\text { peers } \\
\text { It's like my food diary } \\
\text { Others (e.g. don't take photos) }\end{array}$ & $\begin{array}{c}117(34.5) \\
57(16.8) \\
14(4.1) \\
\end{array}$ & & & & \\
\hline a & $\begin{array}{l}\text { Strongly } \\
\text { disagree }\end{array}$ & Disagree & $\begin{array}{c}\text { Frequency }(\%) \\
\text { Neither } \\
\text { agree nor } \\
\text { disagree } \\
\end{array}$ & Agree & $\begin{array}{c}\text { Strongly } \\
\text { agree }\end{array}$ \\
\hline : & & & & & \\
\hline $\begin{array}{l}\text { If I came across food safety- } \\
\text { related news, I often check for } \\
\text { its authenticity }\end{array}$ & 2.1 & 9.1 & 24.2 & 44.5 & 20.1 \\
\hline $\begin{array}{l}\text { I verify the news using other } \\
\text { sources: e.g. media, other } \\
\text { social network, international } \\
\text { news, journal, magazines, } \\
\text { Google }\end{array}$ & 1.8 & 4.4 & 20.1 & 53.1 & 20.6 \\
\hline $\begin{array}{l}\text { Usage and creation of social } \\
\text { media content on food } \\
\text { safety related items }\end{array}$ & Never & Seldom & $\begin{array}{l}\text { Frequency }(\%) \\
\text { Sometimes }\end{array}$ & Often & Always \\
\hline $\begin{array}{l}\text { I create food safety related } \\
\text { content (e.g. sharing views } \\
\text { about hygienic food stalls) to } \\
\text { share online }\end{array}$ & 49.0 & 28.0 & 17.4 & 4.7 & 0.9 \\
\hline $\begin{array}{l}\text { I write food-related blogs and } \\
\text { share food safety advice }\end{array}$ & 64.3 & 18.3 & 11.8 & 5.0 & 0.6 \\
\hline $\begin{array}{l}\text { I promptly share food safety } \\
\text { news with my online peers }\end{array}$ & 25.7 & 27.7 & 28.9 & 15.6 & 2.1 \\
\hline $\begin{array}{l}\text { I read food safety news but } \\
\text { don't share them }\end{array}$ & 8.3 & 16.2 & 31.6 & 34.5 & 9.4 \\
\hline $\begin{array}{l}\text { If I experienced a food safety } \\
\text { related problem (e.g. discover a } \\
\text { fly in the meal or product that } \\
\text { has expired in the shop) I will } \\
\text { take a picture and share it } \\
\text { online }\end{array}$ & 25.7 & 30.4 & 28.9 & 10.6 & 14.4 \\
\hline $\begin{array}{l}\text { I share food safety news to } \\
\text { encourage others to be aware } \\
\text { and take precaution }\end{array}$ & 6.2 & 9.1 & 32.2 & 41.3 & 11.2 \\
\hline $\begin{array}{l}\text { I share the food safety news } \\
\text { once I've verified its } \\
\text { authenticity }\end{array}$ & 11.8 & 13.3 & 28.9 & 33.6 & 12.4 \\
\hline $\begin{array}{l}\text { I provide my views or } \\
\text { comments when sharing the } \\
\text { food safety news }\end{array}$ & 23.9 & 25.7 & 30.7 & 15.9 & 3.8 \\
\hline
\end{tabular}


